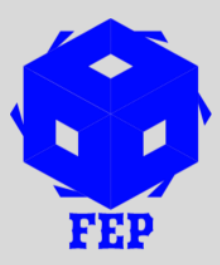

\title{
EXTRACTION AND STRUCTURE ELUCIDATION OF FUCOIDAN FROM MARINE SEAWEED PADINA TETRASTROMATICA HAUCK (PHAEOPHYCEAE)
}

\author{
Poonam Sethi ${ }^{1}$
}

${ }^{1}$ Assistant Professor, Guru Nanak College (Autonomous),

Chennai, India

*Corresponding Author: Poonam Sethi

Article Received: 16-04-20 Accepted: 13-05-20

Published: 10-06-20

Licensing Details: Author retains the right of this article. The article is distributed under the terms of the Creative Commons Attribution-NonCommercial 4.0 License (http://www.creativecommons.org/licences/by-nc/4.0/) which permits non-commercial use, reproduction and distribution of the work without further permission provided the original work is attributed as specified on the Journal open access page.

\section{ABSTRACT}

Seaweeds or the marine macroalgae are one of God's greatest gift to us through Mother Ocean. The members of Phaeophyceae are exclusively marine and are known for their wide range of diversity and they are rich in cell wall polysaccharide fucoidan and alginate. Fucoidan is a general term for all the fucose-containing polysaccharides from brown seaweeds, while 'fucan' will be reserved for the polysaccharide built up with $95 \%$ fucose it's a sulphated polysaccharide. Its highly economical and has abundance applications in the field of pharmaceuticals. Padina tetrastromatica a seaweed abundant in Indian shores was used for the extraction of Fucoidan. Later the structure was elucidated and compared with that of dextran sulphate. This was compared to that of dextran sulphate a standard chemical sulphated polysaccharide while this sulphated polysaccharide is from a natural source.

Keywords: Padina, Fucoidan, Dextran Sulphate, Phytochemical, Phaeophyceae.

\section{INTRODUCTION}

Seaweeds offer us amazing health benefits. They are the most nutritious and rich in vitamins and minerals than any other food. They are also one of nature's richest sources of vegetable protein and provide full spectrum of carotenes, chlorophyll, enzymes, amino acids and fibre in large quantities. The distinctive salty taste of marine plants is due to a balanced chelated combination of sodium, potassium, calcium, magnesium, phosphorus, iron and trace minerals. The levels of these minerals are ten to twenty times the total mineral content of land plants.

Phaeophycean algae are a conspicuous intertidal component that extends from the littoral to the sub-littoral zones of the rocky shores in the tropical oceanic waters. Brown algae are all 
multicellular and their photosynthetic pigments are chlorophyll a, chlorophyll c1-c2, $\beta$ carotene and fucoxanthin. The pigment fucoxanthin in combination with tannins gives the plants their characteristic brown colour (South and Whittick, 1987). The food reserves are laminarin and mannitol. The cell walls of these algae are two layered with an inner layer of cellulose and an outer layer of alginic acid and fucoidin (Hussein et al.,1980, Berteau and Mulloy ,2003, Li et al.,2008,Usov, and Bilan, 2009, Ale and Meyer,2013). Both alginic acid and fucoidan are of considerable commercial value. These two phycocolloids are used widely in the manufacture of many consumer goods. Algin is found within the cell walls of brown algae and it is an emulsifier used in food products. Fucans, the slimy stuff found on kelps also have potential medicinal uses (South and Whittick, 1987).

The aim of the present study is to extract fucoidan from Padina tetrastromatica Hauck and to identify the active principle involved for exploitation for human welfare.

\section{MATERIALS AND METHOD}

The algal samples were collected from the rocky shores of Kanyakumari district (latitude $80^{\circ}$ $\mathrm{N})$, Tamil Nadu during the month of April,

Phycocolloids in the experimental alga was extracted and estimated. The yield for extractable fucoidan in the tissues of Padina tetrastromatica (Table 1).

Extraction of fucan was done following the method outlined by Preeprame et al. (2001) with some modifications. Fucoidan was extracted from the algae with water at room temperature and purified through ethanol precipitation. Ten grams of the powdered seaweed was extracted with water under mechanical stirring, for 12 hours at $25^{\circ} \mathrm{C}$ which was later centrifuged. The supernatant was concentrated and the residue was discarded. The salt solution was reprecipitated with $100 \mathrm{~mL}$ of $80 \%$ ethanol and the ethanol insoluble material was concentrated, dialyzed against water and lyophilized to yield colourless residue. This was then weighed and the yield was estimated.

\section{RESULTS}

\section{i) Botanical Description}

Plants with fan shaped thalli; 9 - $20 \mathrm{~cm}$ high, $10-30 \mathrm{~cm}$ broad, pale or dark brown in colour with a short stipe, stupose on both surfaces in the basal portion; thallus divided into flabellate or cuneate lobes of about $2-3 \mathrm{~cm}$ wide; piliferous zones occur on both surface alternating with glabrous zones; blade has 4 layers of cells in most part of the blade including the basal part. Apical portion involute with a single row of apical cells followed row of cells in two or three columns for $2-3 \mathrm{~cm}$; tetrasporangial sori of about $200 \mu \mathrm{m}$ width occur on both sides of blade; multicellular vegetative propagules common in basal region. Thallus dioecious with naked antheridial and oogonial sori on only one side of the blade of male or female thalli. Tetrasporangial thalli also are non-indusiate.

\section{ii) Extraction of Fucoidan}

Table 1

\begin{tabular}{|l|l|}
\hline \multirow{2}{*}{ Name of the alga } & $\begin{array}{l}\text { Phycocolloid } \\
\mathbf{m g ~ g}^{-1} \mathbf{~ d r y ~ w t ~ ( m e a n ~} \pm \text { S.E) }\end{array}$ \\
\cline { 2 - 2 } & Fucoidan \\
\hline Padina tetrastromatica & \multicolumn{1}{|c|}{$112.0 \pm 0.02$} \\
\hline
\end{tabular}


10 gram of the alga in $100 \mathrm{ml}$ of distilled water would yield nearly $100 \mathrm{mg}$ of dry weight of phyco colloid.

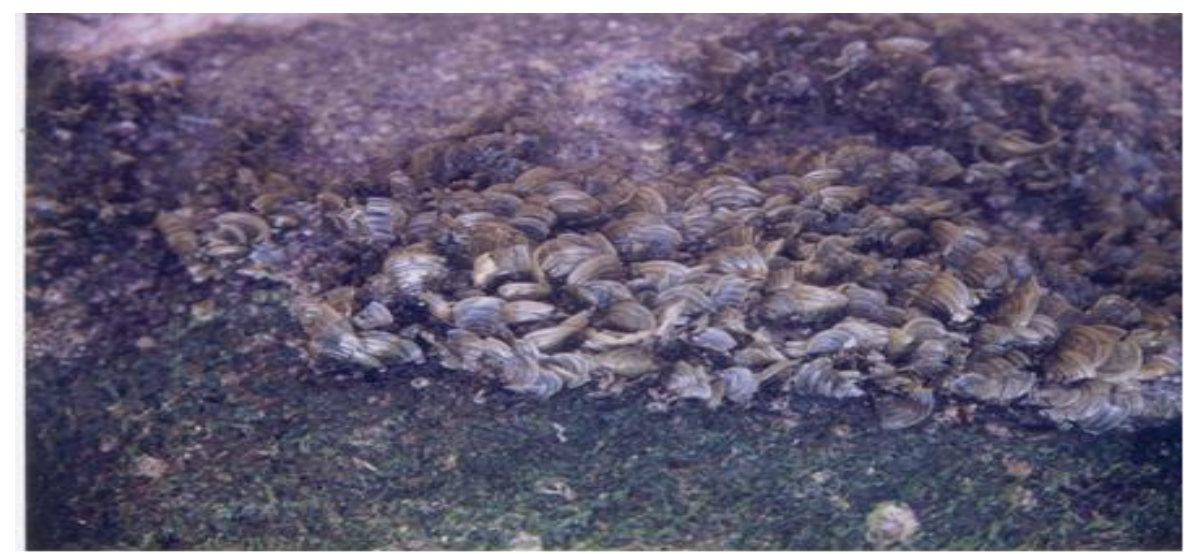

\section{iii)Structure Elucidation}

The FT-IR spectra of Padina tetrastromatica (Fig. 2) showed absorptions that could be attributed to $\gamma(\mathrm{CH})$ vibration $\left(\mathrm{CH}_{2}\right.$ - stretching), $\alpha, \beta$ unsaturated $\gamma(\mathrm{C}=\mathrm{O})$ vibrations, $\gamma(\mathrm{O}-\mathrm{H})$ vibration ( $\mathrm{OH}$ group $-\mathrm{H}$ bonding), $\delta(\mathrm{C}-\mathrm{H})$ vibrations and $\gamma\left(\mathrm{CH}_{2}-\mathrm{CH}_{2}\right)$ rocking vibrations

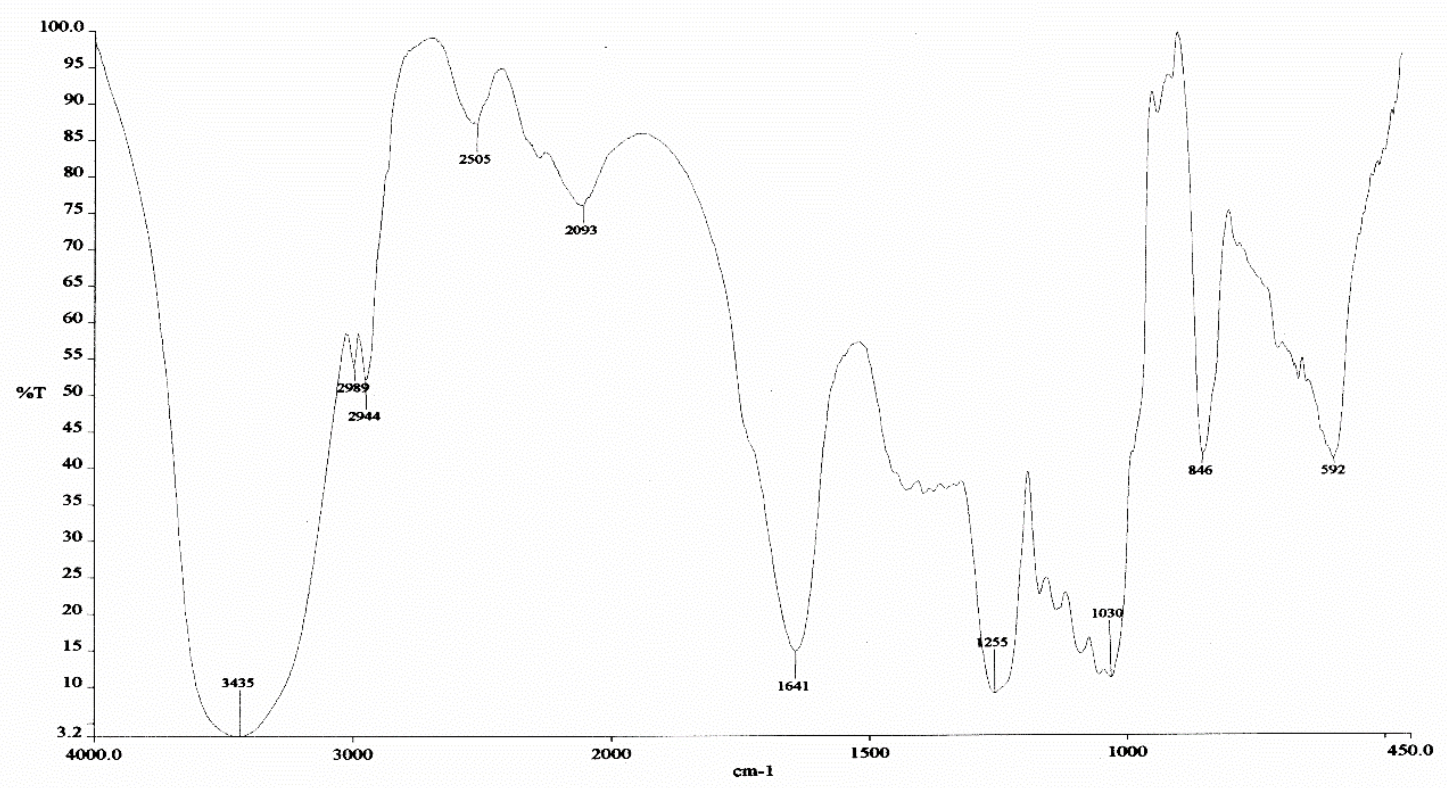

The absorption at $1162 \mathrm{~cm}^{-1}$ could be assigned to $\alpha$-cyclic tertiary bond vibration - suggestive of the conjunction of two rings through $-\mathrm{O}$ - linkage in 1,3 or 1,4 position to the $-\mathrm{OH}$ substituted carbon. The absorption at $1030 \mathrm{~cm}^{-1}$ corresponds to $\mathrm{C}-\mathrm{O}-\mathrm{C}$ vibration. The absorption at $2944 \mathrm{~cm}^{-1}$ and $2505 \mathrm{~cm}^{-1}$ might indicate methyl groups. Low energy vibrations such as rocking are observed in the region from $600 \mathrm{~cm}^{-1}$ to $800 \mathrm{~cm}^{-1}$ which could indicate glycosidic linkages (Fig. 2). A sharp intense peak around $1641 \mathrm{~cm}^{-1}$ may be attributed to $\alpha, \beta$ unsaturated carbonyl group, which is different from the simple saturated carbonyl one. 
This was compared to that of dextran sulphate a standard chemical sulphated polysaccharide while this sulphated polysaccharide is from a natural source

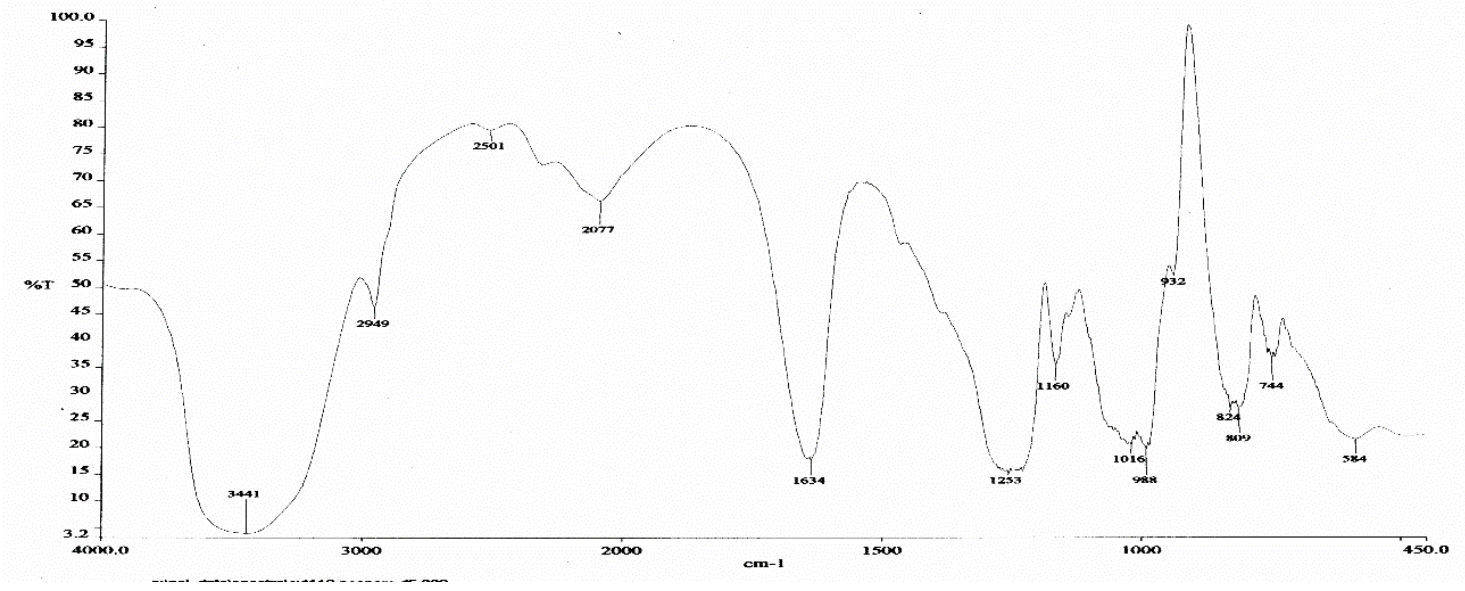

\section{Discussion}

A perusal of literature indicates that the initial studies on Indian algae were confined to macrophytic seaweeds and Phaeophyta are exclusively marine and are known for their wide range of diversity in morphology, anatomy, and reproduction. Thalli show a high degree of tissue differentiation in the advanced forms with cell wall polysaccharides or phyco colloids. The study of the chemical structure and properties of unusual metabolic products of marine life is a subject where marine ecology and experimental sciences of chemistry, biochemistry, pharmacology and medicine share a common and complimentary interest. Over the past decade, chemical investigations of benthic marine algae have illustrated that these organisms produce a wide variety of structurally unique and biologically active secondary metabolites. The brown algae, particularly, the members of Dictyotaceae, Cystoseiraceae and Sargassaceae are known to yield complex secondary metabolites and sulfated polysaccharides that possess various types of biological activities and their applications as antibiotics and other drugs remain to be understood (Percival,1968). Biomedical applications of algal polysaccharides have been reviewed (Kitamura et al., 1991, Zvyagintseva et al.,1999, Li et al.,2004). Although numerous uses for algal polysaccharides have been established, the majority of applications involve the use of their physical properties rather than their physiological properties. Antimicrobial potential of algae and their products have been extensively studied in the past four decades

The presence of sulphated group and comparison with that of dextran sulphate confirms its PHYCO COLLOIDAL NATURE. Polysaccharides other than fucans from experimental alga are alginic acid. Alginic acid is a carboxylated polysaccharide and does not contain sulphates.

\section{References}

Ale, M.T., \& Meyer, A.S. (2013). Fucoidans from brown seaweeds: an update on structures, extraction techniques and use of enzymes as tools for structural elucidation, RSC Advances,3,8131-8141.

Berteau, O., \& Mulloy, B. (2003). Sulfated fucans, fresh perspectives: structures, functions, and biological properties of sulfated fucans and an overview of enzymes active toward this class of polysaccharide, Glycobiology, 13(6), 29-40. 
Hayashi, P.K., Lee, J.B., Sankawa, U., \& Hayashi, T. (2001). A Novel Antivirally Active Fucan Sulfate Derived from an Edible Brown Alga, Sargassum horneri. Chemical and Pharmaceutical Bulletin. 49(4), 484-485.

Hussein, M.M.D., Abdel-Aziz, A., \& Salem, H.M. (1980). Some structural features of a new sulphated heteropolysaccharide from Padina pavonia, Phytochemistry, 19, 21332135.

Kitamura, K., Matsuo, M., \& Yasui, T. (1991). Fucoidan from brown seaweed Laminaria angustata var. longissima. Agricultural and Biological Chemistry, 55(2), 615-616.

Li, B., Gu, X.H., \& Xu, S.Y. (2004). Determination of the position of sulphate group in sulphated polysaccharides. Journal of Analytical Science, 20, 498-500.

Li, B., Lu, F., Wei, X., \& Zhao, R.X. (2008). Fucoidan: structure and bioactivity, Molecules, $13,1671-1695$.

Percival, E. (1968). Glucoroxylofucan, a cell-wall component of Ascophyllum nodosum. Carbohydrate Research, 7(3), 272-283.

South, R.G., \& Whittick, A. (1987). Introduction to Phycology. Blackwell Scientific Publications, Oxford, London

Usov, A.I., \& Bilan, M.I. (2009). Fucoidans-sulfated polysaccharides of brown algae. Russian Chemical Reviews, 78(8), 785-799.

Zvyagintseva, T.N., Shevchenko, N.M., \& Popivnich, I.B. (1999). A new procedure for the separation of water-soluble polysaccharides from brown seaweeds. Carbohydrate Research, 322, 32-39. 